\title{
Perkembangan Terkini Terapi Sistemik Psoriasis
}

\author{
Natalia Rania Sutanto, Windy Keumala Budianti \\ Departemen Dermatologi dan Venereologi, Fakultas Kedokteran Universitas Indonesia, \\ RSUPN dr. Cipto Mangunkusumo, Jakarta, Indonesia \\ Alamat Korespondensi:nr_sutanto@yahoo.com
}

\begin{abstract}
Abstrak
Psoriasis merupakan penyakit inflamasi kulit akibat aktivasi terhadap sistem imun bawaan dan adaptif. Etiopatogenesis psoriasis merupakan proses kompleks dan multifaktorial, yang dipengaruhi oleh faktor genetik dan lingkungan seperti stres, trauma, dan infeksi. Pada pasien dengan psoriasis kategori sedang hingga berat dan lesi lokalisata di area skalp, wajah, kuku, telapak tangan dan kaki, serta genital merupakan indikasi untuk pemberian terapi dengan obat sistemik. Saat ini terdapat berbagai pilihan terapi sistemik yang tersedia yaitu obat sistemik konvensional, terapi small molecules, obat biologik, dan biosimilarnya yang terdiri atas inhibitor TNF- $\alpha$, inhibitor IL-12/23, inhibitor IL-17, dan inhibitor IL-23. Selama dekade terakhir, tata laksana psoriasis telah mengalami pergeseran paradigma yaitu obat biologik dan biosimilarnya mulai menjadi pilihan utama karena telah terbukti memiliki efikasi yang lebih kuat dengan efek samping minimal. Tinjauan pustaka ini membahas perkembangan terapi sistemik psoriasis terkini sehingga diharapkan dapat memberikan acuan untuk memilih terapi yang tepat, efektif, dan aman untuk pasien psoriasis.
\end{abstract}

Kata kunci: biosimilar, obat biologik, psoriasis, small molecules, terapi sistemik

\section{Current Systemic Therapy for Psoriasis}

\begin{abstract}
Psoriasis is a chronic inflammatory skin disease caused by disturbances in the innate and adaptive immune systems. The etiopathogenesis of psoriasis is a complex and multifactorial process, which is influenced by genetic and environmental factors such as stress, trauma, and infection. Patients with moderate to severe psoriasis and localized lesions of the scalp, face, nails, palms, feet, and genitals are an indication for therapy with systemic drugs. Currently, there are various systemic therapy options available, namely conventional systemic drugs, small molecules, as well as biologics and biosimilars consisting of TNF- $\alpha$ inhibitor, IL-12/23 inhibitor, IL-17 inhibitor, and IL-23 inhibitor. Over the last decade, the management of psoriasis has undergone a paradigm shift. Biologics and their biosimilars are becoming the main choice of treatment due to their higher efficacy and minimal side effects compare to the conventional systemic therapy. This literature review discusses the latest systemic therapeutic modalities, so that they can provide a reference in choosing the effective and safe therapies for psoriasis patients.
\end{abstract}

Keywords: biosimilar, biological medicine, psoriasis, small molecules, systemic therapy 


\section{Pendahuluan}

Psoriasis merupakan penyakit inflamasi kulit yang dimediasi sistem imun, ditandai oleh peradangan kulit, hiperplasia epidermis, dan pemanjangan rete ridges. Psoriasis dapat menyerang berbagai usia, namun terdapat distribusi bimodal yaitu sering ditemukan pada usia 18-39 dan 50-69 tahun. Terdapat 125 juta orang di dunia mengalami psoriasis, dengan prevalensi bervariasi di berbagai negara. ${ }^{1}$ Saat ini tersedia berbagai pilihan terapi untuk pasien psoriasis, mulai dari terapi topikal, fototerapi, dan obat sistemik. Pasien dengan psoriasis kategori sedang hingga berat merupakan indikasi untuk pemberian terapi sistemik.

Ada beberapa pilihan terapi sistemik yang tersedia yaitu obat konvensional (metotreksat, siklosporin, asitretin) yang sudah ada sejak tahun 1972, small molecules, obat biologik, dan biosimilar. Selama dekade terakhir, tata laksana psoriasis telah mengalami pergeseran paradigma yaitu obat biologik dan biosimilarnya mulai menjadi pilihan utama karena menargetkan mediator imun spesifik yang berperan pada etiopatogenesis psoriasis, yaitu TNF- $\alpha$, IL-17, dan IL-23. ${ }^{2}$

Saat ini obat biologik sebagai terapi target telah terbukti memiliki efektivitas lebih baik, mampu mencapai penurunan skor psoriasis area severity index (PASI) sebesar $\geq 90 \%$ dan $100 \%$ dari baseline, dengan efek samping minimal. Obat biologik merupakan pilihan terapi untuk pasien dengan psoriasis tipe plak derajat sedang hingga berat yang tidak responsif atau terdapat kontraindikasi terhadap obat sistemik konvensional dan fototerapi. ${ }^{3,4}$ Berikut dibahas mengenai small molecules, obat biologik, dan biosimilarnya yang ada sejak 5 tahun terakhir. Data diambil dari meta analisis, telaah sistematis, dan uji acak tersamar yang merupakan level of evidence terbaik untuk terapi.

\section{Etiopatogenesis}

Etiopatogenesis psoriasis merupakan proses yang kompleks, dipengaruhi oleh faktor genetik, lingkungan, infeksi, gaya hidup, dan aktivasi sistem imun yang berlebihan. Sekurangnya terdapat 60 lokus kromosom yang terkait dengan kerentanan psoriasis, lokus yang paling dominan adalah PSORS1 (50\%). Lokus PSORS1 terletak pada kromosom $6 \mathrm{p} 21$ di dalam major histocompatibility complex (MHC) kelas I HLA-B, yang berhubungan dengan human leukocyte antigen (HLA)-Cw6. Adanya HLA-Cw6 dikaitkan dengan psoriasis awitan dini dan akut, serta meningkatkan risiko psoriasis 9-23 kali lipat. Faktor lain yang dapat memicu psoriasis antara lain trauma pada kulit yang dikenal sebagai fenomena Koebner, infeksi oleh Streptococcus, stres emosional, obesitas, perokok berat, dan obat seperti $\beta$-blocker dan litium. ${ }^{1,5,6}$

Terdapatnya aktivasi berlebihan terhadap sistem imun bawaan dan adaptif dianggap sebagai dasar patogenesis psoriasis. Jika terdapat kerusakan atau rangsangan pada kulit, keratinosit yang rusak akan melepaskan "sinyal bahaya" berupa asam nukleat, protein S100, katelisidin, $\beta$ defensins, produk mikroba (lipopolisakarida bakteri), serta sitokin proinflamasi IL-1, IL-36, dan IL-8. Sel dendritik plasmasitoid, keratinosit, natural killer $T$ cells, dan makrofag menyekresi sitokin yang akan mengaktivasi sel dendritik mieloid. Sel dendritik mieloid yang sudah teraktivasi akan menyekresi IL-12 dan IL-23, kemudian IL-12 akan menginduksi diferensiasi sel $\mathrm{T}$ menjadi sel Th1, sedangkan IL-23 berperan penting dalam proliferasi Th17 dan Th22. Sel Th1 kemudian akan menyekresi interferon gamma (INF- $\gamma$ ) dan tumor necrosis factor $\alpha$ (TNF- $\alpha$ ), Th22 akan menyekresi IL-22, sedangkan Th 17 akan menyekresi IL-17, IL-22, dan TNF- $\alpha$ (Gambar 1). 1,5,6

Secara bersamaan keratinosit meningkatkan produksi mediator inflamasi (IL-1, IL-36), dan sejumlah besar kemokin, termasuk IL-8 (CXCL8), CXCL9, dan CXCL10. Keratinosit yang teraktivasi juga terus melepaskan "sinyal bahaya" yaitu protein $\mathrm{S} 100$, katelisidin, dan $\beta$-defensin dalam jumlah banyak yang memiliki sifat antimikroba dan kemotaktik sehingga menyebabkan terjadi kemotaksis dan perekrutan sel inflamasi lainnya (makrofag, sel dendritik, neutrofil, dan subset sel T lainnya), yang bertindak secara sinergis untuk mempertahankan proses penyakit. Berdasarkan semua jalur tersebut, aktivasi Th17 yang dimediasi oleh IL-23 dianggap sebagai jalur yang paling dominan. Sinyal IL-23 dimediasi intraselular melalui Tyk2-Jak2 dan STAT3 yang akan menyebabkan transkripsi mediator inflamasi. Sitokin tersebut akan berperan dalam proliferasi keratinosit, meningkatkan ekspresi mediator angiogenik dan molekul adhesi endotel, serta inflitrasi sel imun ke lesi kulit., 1,5,6 
Saat ini aktivasi oleh sel tissue resident memory $T$ ( $\left.\mathrm{T}_{\mathrm{RM}}\right)$ juga dianggap berkontribusi dalam patogenesis psoriasis. Sel $\mathrm{T}_{\mathrm{RM}}$ merupakan bagian dari sel $\mathrm{T}$ memori yang berada di jaringan, dapat bertahan dalam jangka waktu lama tanpa antigen, dan tidak bersirkulasi dalam darah. Sel $\mathrm{T}_{\mathrm{RM}}$ dapat bekerja sebagai pertahanan selular adaptif yang memberikan imunitas lokal secara cepat terhadap infeksi. Terdapat 20 juta sel $\mathrm{T}_{\mathrm{RM}}$ pada permukaan kulit, jumlahnya lebih banyak dibandingkan dengan sel $\mathrm{T}$ yang ada di sirkulasi. Sel $\mathrm{T}_{\mathrm{RM}}$ adalah sel CD8+ yang mengekspresikan CD103 dan CD69. Sel CD103 berikatan dengan $E$ cadherin sehingga menyebabkan retensi sel pada jaringan epitel, sedangkan CD69 yang merupakan penanda aktivasi sel $\mathrm{T}$ berperan dalam menghambat sphingosine 1-phosphate receptor 1 (S1PR1) yang juga menghalangi keluarnya dari jaringan. Sel $T_{R M}$, CD103, dan CD69 masih dapat ditemukan pada lesi psoriasis yang sudah sembuh atau pada kulit non lesi/lesi naif. Sel $\mathrm{T}_{\mathrm{RM}}, \mathrm{CD} 103$, dan CD69 akan memproduksi IL-17A dan IL-22, serta mengekspresikan reseptor IL-23 sehingga jika teraktivasi dapat menimbulkan lesi psoriasis (lesi rekuren) dan menjadi kronis. ${ }^{7-10}$

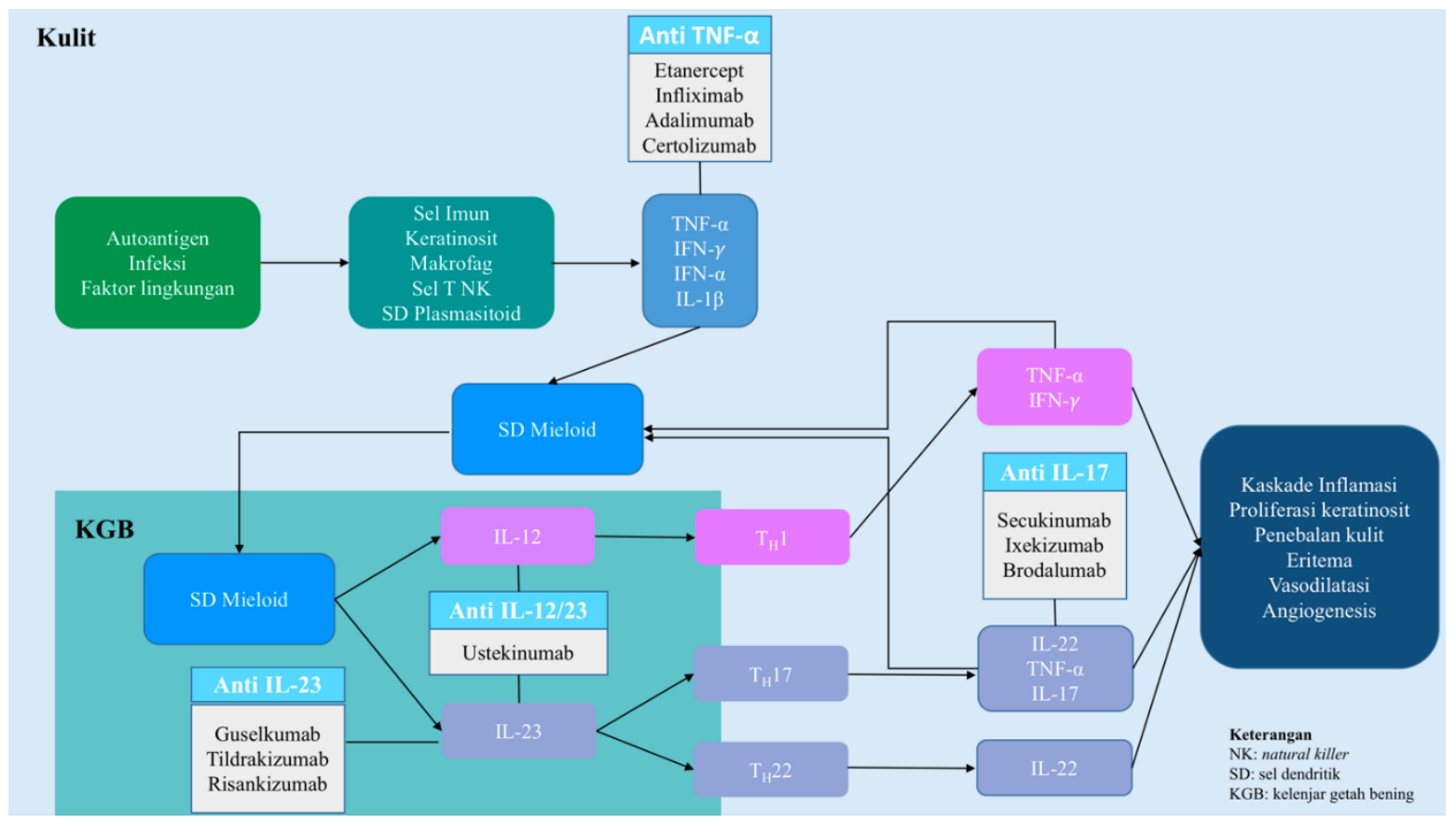

Gambar 1. Etiopatogenesis Psoriasis dan Dasar Pengobatan Obat Biologik ${ }^{1}$

\section{Pemilihan Terapi Berdasarkan Derajat Keparahan}

Pemilihan terapi psoriasis antara lain didasari oleh pembagian derajat keparahan psoriasis berdasarkan alur tata laksana yang dikeluarkan oleh Perhimpunan Dokter Spesialis Kulit dan Kelamin Indonesia (PERDOSKI), untuk psoriasis tipe plak dan tipe psoriasis berat, yaitu psoriasis tipe eritroderma dan psoriasis pustulosa generalisata. Pasien dengan psoriasis kategori sedang hingga berat merupakan indikasi untuk pemberian terapi obat sistemik. Tingkat keparahan psoriasis tipe plak umumnya ditentukan oleh total area permukaan tubuh/body surface area (BSA) yang terlibat. Psoriasis menurut BSA diklasifikasikan menjadi 3 kategori yaitu ringan
$(<3 \%)$, sedang $(3-10 \%)$, dan berat $(>10 \%)$. Psoriasis juga masuk dalam kategori berat apabila mengenai area yang sulit diobati dan sangat memengaruhi kualitas hidup, yaitu area skalp, wajah, genital, kuku, palmar, dan plantar tanpa melihat presentase BSA. Terdapat alat ukur yang menilai kualitas hidup pasien psoriasis, yaitu dermatology life quality index (DLQI) yang diklasifikasikan menjadi 3 kategori, yaitu ringan $(<5)$, sedang $(5-10)$, dan berat $(>10){ }^{11}$

Selain menggunakan BSA dan DLQI, terdapat alat ukur untuk memantau derajat keparahan dan efektivitas terapi yaitu PASI (psoriasis area severity index). ${ }^{3,12}$ Skor PASI tidak hanya memperhitungkan BSA tetapi juga intensitas kemerahan, skuama, dan ketebalan plak yang pada akhirnya menghasilkan skor dari 0 (tidak ada 
penyakit) hingga 72 (tingkat keparahan penyakit maksimal). Skor PASI diklasifikasikan menjadi 3 kategori, yaitu ringan $(<5)$, sedang $(5-10)$, dan berat ( $>10)$. Skor PASI-75 didefinisikan sebagai penurunan skor PASI sebesar $\geq 75 \%$ dari baseline. Skor PASI-90 dan PASI-100 didefinisikan sebagai penurunan skor PASI sebesar $\geq 90 \%$ dan $100 \%$ dari baseline. Skor PASI-75 dianggap sebagai baku emas penilaian efektivitas dalam uji acak terkontrol, namun sebaiknya target terapi harus mencapai kulit bebas lesi atau hampir bersih (PASI-90 atau PASI-100). ${ }^{13,14}$

Psoriasis juga dianggap berat apabila terdapat salah satu penyakit penyerta, antara lain psoriasis artritis, inflammatory bowel disease (IBD), gangguan psikologis/psikiatri, dan uveitis. Saat ini sindrom metabolik, kardiovaskular, aterosklerosis, nonalcoholic fatty liver disease, limfoma, sleep apnea, cronic obstructive pulmonary disease (COPD), osteoporosis, Parkinson's disease, celiac disease, dan disfungsi ereksi juga dianggap sebagai komorbid. ${ }^{11}$ Pemilihan terapi harus mempertimbangkan tipe psoriasis, keparahan klinis, komorbiditas, riwayat pengobatan, tolerabilitas, efektivitas, keamanan, dan pilihan pasien. ${ }^{6,12}$

\section{Pilihan Terapi}

Terdapat beberapa pilihan terapi sistemik, antara lain terapi konvensional, small molecules, obat biologik, dan biosimilarnya. Obat sistemik konvensional saat ini sudah mulai ditinggalkan di beberapa negara, karena target pengobatan saat ini adalah mencapai PASI-90 atau PASI-100, yang umumnya sulit dicapai dengan terapi tersebut. Berdasarkan telaah sistematis dan meta analisis, terapi dengan obat biologik menunjukkan keunggulan yang signifikan dibandingkan dengan terapi small molecules dan obat sistemik konvensional, tetapi terapi small molecules juga menunjukkan keunggulan dibandingkan dengan obat sistemik konvensional. ${ }^{13}$

\section{Small Molecules}

Terapi small molecules memiliki beberapa keunggulan jika dibandingkan obat biologik, yaitu dapat berdifusi ke dalam sel dan target pada jalur pensinyalan intraseluler. Keunggulan lainnya dapat diformulasikan untuk pemberian oral dan memiliki penetrasi yang baik sehingga berpotensi untuk pemberian topikal, serta memiliki biaya produksi yang lebih rendah dibandingkan dengan obat biologik. Namun, terapi small molecules juga memiliki kelemahan yaitu memiliki selektivitas target yang lebih rendah sehingga menunjukkan efektivitas yang lebih rendah dibandingkan dengan obat biologik. ${ }^{2}$ Terapi small molecules yang akan dibahas antara lain apremilast dan tofacitinib.

\section{Apremilast}

Apremilast merupakan inhibitor selektif enzim phosphodiesterase 4 (PDE4). Enzim PDE4 berfungsi mendegradasi cyclic adenosine monophosphate (cAMP) secara intraselular, maka bila terinhibisi cAMP akan meningkat dan menyebabkan peningkatan aktivitas $c A M P$ response element binding protein dan menginhibisi sinyal NF-kB, sehingga menghambat produksi mediator proinflamasi. ${ }^{6}$ Apremilast disetujui oleh FDA sebagai terapi psoriasis pada tahun 2014. Apremilast diberikan mulai dari dosis $10 \mathrm{mg}$ pada hari pertama, kemudian dititrasi hingga mencapai dosis $30 \mathrm{mg}$ yang diberikan 2 kali sehari pada akhir minggu pertama. Setelah itu dosis dilanjutkan dengan $30 \mathrm{mg}$ yang diberikan dua kali sehari. Pada pasien dengan gangguan ginjal (kadar creatinine clearance $<30 \mathrm{~mL} / \mathrm{min}$ ), dosis apremilast dapat diturunkan menjadi $30 \mathrm{mg}$ yang diberikan satu kali sehari. Efek samping yang mungkin timbul antara lain perburukan depresi, mual, diare, penurunan berat badan, infeksi saluran napas atas, dan sakit kepala. ${ }^{6,12}$

Terdapat suatu penelitian crossover pada 844 pasien psoriasis tipe plak derajat berat, sebagian mendapatkan apremilast $30 \mathrm{mg}$ dua kali sehari dan sisanya mendapat plasebo. Pada minggu ke-16, kelompok plasebo diubah untuk mendapatkan apremilast sampai minggu 52. Sedangkan pada minggu ke-32, 154 pasien dari kelompok apremilast yang telah mencapai PASI-75 dirandomisasi ulang untuk melanjutkan apremilast atau beralih ke plasebo hingga minggu ke-52. Skor PASI-75 pada minggu ke 16 lebih tinggi pada kelompok apremilast dibandingkan dengan kelompok plasebo (33,1\% dan 5,3\%). Dari 77 pasien yang dirandomisasi ulang pada minggu ke32 untuk menerima apremilast, $61 \%$ pasien mempertahankan PASI-75 sampai minggu ke-52. Dari 77 pasien lainnya yang dirandomisasi untuk mendapat plasebo pada minggu ke-32, 83,11\% kehilangan respons PASI-75 dan hanya $11,7 \%$ mencapai PASI-75 pada minggu ke-52. ${ }^{15}$

Kontraindikasi absolut pemberian apremilast antara lain riwayat hipersensitivitas terhadap obat 
ini, sedangkan kontraindikasi relatif berupa depresi. Saat ini masih belum diketahui efek keamanan jangka panjang penggunaan apremilast. Untuk pemantauan terapi, tidak ada pemeriksaan laboratorium khusus. Apremilast mempunyai level of evidence I dengan rekomendasi A dan kategori kehamilan $\mathrm{C}^{12}$

\section{Tofacitinib}

Tofacitinib merupakan obat yang menginhibisi tirosin kinase JAK1 dan JAK 3, serta JAK2 secara minimal. Janus kinase berperan dalam menurunkan sinyal beberapa sitokin proinflamasi, termasuk IL2, IL-4, IL-9, IL- 13, IL-21, pensinyalan IFN tipe I dan II, IL-6. Pada tingkat yang lebih rendah juga menurunkan IL-12 dan IL-23. Tofacitinib dapat dipertimbangkan untuk pengobatan psoriasis sedang hingga berat, namun untuk indikasi tersebut sampai saat ini belum disetujui oleh FDA. ${ }^{12}$ Tofacitinib diberikan 2 kali sehari dengan dosis 5$10 \mathrm{mg}$. Efek samping yang mungkin ditimbulkan antara lain supresi sumsum tulang, infeksi saluran napas atas, nasofaringitis, infeksi (bakteri, virus, jamur, terutama pneumonia, selulitis dan herpes zoster), keganasan (limfoma, paru, dan payudara) dan diare. ${ }^{16}$

Terdapat 2 studi fase III (OPT Pivotal 1 dan OPT Pivotal 2) yang menentukan efektivitas dan keamanan tofacitinib oral dosis $5 \mathrm{mg}$ dan $10 \mathrm{mg}$ dua kali sehari dibandingkan dengan plasebo pada pasien dengan psoriasis plak derajat sedang hingga berat. Pada OPT Pivotal 1 dan OPT Pivotal 2, didapatkan 745 pasien menerima tofacitinib $5 \mathrm{mg}$, 741 menerima tofacitinib $10 \mathrm{mg}$, dan 373 menerima plasebo. Pada minggu ke-16, sebagian besar pasien mencapai Physicians' Global Assessment (PGA) of 'clear' or 'almost clear' dengan tofacitinib 5 dan $10 \mathrm{mg}$ dua kali sehari dibandingkan plasebo (OPT Pivotal 1: 41,9\%, 59,2\%, 9\%; OPT Pivotal 2: 46\%, 59,1\%,10,9\%). PASI-75 dari OPT Pivotal 1 didapatkan hasil $39,9 \%, 59,2 \%$ dan 6,2\%, sedangkan OPT Pivotal 2 didapatkan PASI-75 pada 46\%, 59,6\% dan 11,4\% untuk tofacitinib $5 \mathrm{mg}, 10 \mathrm{mg}$ dua kali sehari dan, plasebo. Efek samping yang paling sering muncul pada seluruh kelompok yaitu nasofaringitis. Dua belas pasien melaporkan herpes zoster di seluruh kelompok pengobatan tofacitinib di kedua studi. ${ }^{17}$

Pemantauan yang disarankan antara lain pemeriksaan darah perifer lengkap, fungsi ginjal, fungsi hepar, dan profil lipid. Sebelum memulai terapi, pasien perlu melakukan skrining infeksi tuberkulosis, hepatitis, dan HIV. Kontraindikasi absolut pemberian tofacitinib jika hitung jenis limfosit $<500 \mathrm{sel} / \mathrm{mm}^{3}$, neutrofil $<1000 \mathrm{sel} / \mathrm{mm}^{3}$, atau $\mathrm{Hb}<9 \mathrm{~g} / \mathrm{dL}$. Sedangkan kontraindikasi relatif berupa infeksi, pasien dengan risiko perforasi gastrointestinal, riwayat keganasan dan penyakit limfoproliferatif. ${ }^{16,18}$ Tofacitinib mempunyai level of evidence II-III dengan rekomendasi $\mathrm{B}$ dan kategori kehamilan C. ${ }^{12}$

\section{Obat Biologik}

Berdasarkan sumbernya, saat ini terdapat 3 jenis obat biologik untuk psoriasis, yaitu rekombinan sitokin manusia, antibodi monoklonal, dan protein fusi. Semua obat biologik diberikan melalui subkutan, kecuali infliximab. Secara garis besar, tidak ada peningkatan risiko infeksi atau keganasan pada pasien psoriasis yang menggunakan obat biologik. ${ }^{1}$

Indikasi penggunaan obat biologik antara lain pasien yang membutuhkan terapi sistemik, psoriasis plak derajat sedang (skor PASI 5-10, BSA 3-10\%, DLQI 5-10) sampai berat (skor PASI $>10$, BSA >10\%, DLQI $>10$ ), kurangnya respons terhadap pengobatan sistemik atau fototerapi, memiliki kontraindikasi atau intoleransi terhadap setidaknya salah satu pengobatan sistemik, mengenai area yang sulit diobati (area skalp, wajah, genital, kuku, palmar, dan plantar), psoriasis dengan komorbid, dan psoriasis presisten/cepat relaps. ${ }^{19,20}$

Terdapat 4 kelas obat biologik yang digunakan untuk terapi psoriasis, yaitu inhibitor TNF- $\alpha$ (etanercept, adalimumab, infliximab), inhibitor IL12/23 (ustekinumab), inhibitor IL-17 (secukinumab, ixekizumab, brodalumab), dan inhibitor IL-23 (guselkumab, tildrakizumab, risankizumab). Namun yang akan dibahas hanyalah obat biologik yang baru ada dalam 5 tahun terakhir, yaitu inhibitor IL-17 dan IL-23.

\section{Secukinumab}

Secukinumab merupakan antibodi monoklonal manusia yang secara spesifik menghambat IL-17A. Pada tahun 2015, FDA menyetujui secukinumab untuk tata laksana psoriasis tipe plak derajat sedang-berat, psoriasis artritis, dan ankylosing spondylitis. ${ }^{21}$ Dosis pemberiannya diawali dengan dosis 150 atau $300 \mathrm{mg}$ secara subkutan pada minggu ke-0, 1, 2, 3, dan 4, kemudian dilanjutkan dengan dosis rumatan $300 \mathrm{mg}$ setiap 4 minggu. Efektivitas secukinumab lebih besar pada dosis $300 \mathrm{mg}$ dibandingkan dengan dosis $150 \mathrm{mg}$. 
Namun demikian, dosis $150 \mathrm{mg}$ juga masih dapat diterima untuk beberapa pasien.

Terdapat studi oleh Bissonnette dkk. yang menilai efektivitas secukinumab selama 5 tahun pengobatan pada psoriasis sedang hingga berat. Pada penelitian ini dosis yang digunakan adalah $300 \mathrm{mg}$ setiap 4 minggu. Hasilnya menunjukkan PASI-75/90/100 pada tahun pertama adalah $88,9 \% / 68,5 \% / 43,8 \%$, sedangkan pada akhir tahun ke-5 diperoleh hasil 88,5\%/66,4\%/41\%. Profil keamanan secukinumab relatif baik sampai tahun ke-5. ${ }^{22}$ Efek samping yang dapat terjadi antara lain infeksi (terutama nasofaringitis), mucoctaneous candidiasis, eksaserbasi inflammatory bowel disease (IBD), dan reaksi hipersensitivitas. ${ }^{22,23}$

Kontraindikasi pemberian secukinumab berupa hipersensitivitas terhadap bahan obat, penyakit IBD, dan infeksi aktif. Secukinumab mempunyai level of evidence I-II dengan rekomendasi A dan kategori kehamilan B. ${ }^{21}$

\section{Ixekizumab}

Ixekizumab merupakan antibodi monoklonal IgG4 humanized yang secara spesifik menghambat IL-17A. Pada tahun 2016, FDA menyetujui ixekizumab untuk terapi psoriasis derajat sedangberat dan psoriasis artritis. ${ }^{21}$ Dosis pemberiannya diawali dengan dosis inisial $160 \mathrm{mg}$ secara subkutan pada minggu ke-0, kemudian dilanjutkan dengan dosis rumatan $80 \mathrm{mg}$ pada minggu ke-2, 4, $6,8,10$, dan 12. Setelah minggu ke-12, dosis yang diberikan adalah $80 \mathrm{mg}$ setiap 4 minggu.

Terdapat suatu meta analisis dan telaah sistematis yang membandingkan efektivitas dan keamanan brodalumab, secukinumab, ixekizumab, ustekinumab, guselkumab, tildrakizumab, dan risankizumab dalam pengobatan jangka pendek psoriasis plak derajat sedang sampai berat. Ixekizumab $80 \mathrm{mg}$ setiap 2 minggu menempati peringkat tertinggi dalam pencapaian jangka pendek PASI-75 (SUCRA $=93,0 \%$ ) dibandingkan obat lainnya. Namun, ixekizumab $80 \mathrm{mg}$ setiap 4 minggu juga menduduki peringkat tertinggi dalam risiko penghentian akibat efek samping selama pengobatan jangka pendek. ${ }^{24,25}$

Efek samping yang dapat terjadi antara lain infeksi, mucocutaneous candidiasis, kekambuhan IBD, dan reaksi hipersensitivitas. Kontraindikasi penggunaan ixekizumab berupa hipersensitivitas terhadap bahan obat, dan infeksi aktif. Ixekizumab mempunyai level of evidence I-II dengan rekomendasi A dan kategori kehamilan $\mathrm{B}^{21}$

\section{Brodalumab}

Brodalumab adalah antibodi monoklonal antiIL-17RA humanized yang menargetkan rantai A reseptor IL-17. Pada tahun 2017 brodalumab disetujui oleh FDA untuk psoriasis plak sedang hingga berat pada pasien dewasa yang merupakan kandidat untuk terapi sistemik atau fototerapi, dan gagal berespons atau kehilangan respons terhadap terapi sistemik lainnya. ${ }^{21}$ Dosis pemberiannya diawali dengan dosis $210 \mathrm{mg}$ secara subkutan pada minggu ke-0, 1, dan 2, kemudian dilanjutkan dengan dosis $210 \mathrm{mg}$ setiap 2 minggu.

Terdapat dua studi fase III (AMAGINE-2 dan AMAGINE-3) yang membandingkan efektivitas brodalumab dosis $210 \mathrm{mg}$ dan $140 \mathrm{mg}$, dibandingkan ustekinumab (45 mg jika berat badan $\leq 100 \mathrm{~kg}$ atau $90 \mathrm{mg}$ jika $>100 \mathrm{~kg}$ ) dan plasebo selama 12 minggu. Pada studi AMAGINE-2, PASI-75 tercapai pada $86 \%$ grup dosis $210 \mathrm{mg}$, $67 \%$ dari grup dosis $140 \mathrm{mg}$, dibandingkan $70 \%$ grup ustekinumab dan $8 \%$ plasebo. PASI-100 tercapai pada $44 \%$ grup dosis $210 \mathrm{mg}, 26 \%$ dari grup dosis $140 \mathrm{mg}$, dibandingkan 22\% grup ustekinumab dan $1 \%$ plasebo. Pada studi AMAGINE-3, PASI-75 tercapai pada $85 \%$ grup dosis $210 \mathrm{mg}, 69 \%$ dari grup dosis $140 \mathrm{mg}$, dibandingkan $69 \%$ grup ustekinumab dan $6 \%$ plasebo. PASI-100 tercapai pada $37 \%$ grup dosis $210 \mathrm{mg}, 27 \%$ dari grup dosis $140 \mathrm{mg}$, dibandingkan $19 \%$ grup ustekinumab dan $0,3 \%$ plasebo. ${ }^{21,26}$

Suatu meta analisis dan telaah sistematis melaporkan perbandingan efektivitas dan keamanan brodalumab, secukinumab, ixekizumab, ustekinumab, guselkumab, tildrakizumab, dan risankizumab dalam pengobatan jangka pendek psoriasis plak sedang sampai berat, melaporkan Brodalumab $210 \mathrm{mg}$ menduduki peringkat tertinggi dalam pencapaian jangka pendek PASI100 (surface under the cumulative ranking curve/SUCRA $=85,0 \%$ ) jika dibandingkan dengan obat lainnya. ${ }^{24}$ Selain itu juga terdapat meta analisis dan telaah sistematis lainnya yang membandingkan efektivitas jangka pendek dari terapi sistemik biologis dan non-biologis yang tersedia untuk pasien psoriasis plak sedang hingga berat. Hasilnya juga menunjukkan bahwa brodalumab, ixekizumab, risankizumab, dan guselkumab memiliki tingkat efikasi tertinggi, terutama pada PASI-90 dan PASI-100. ${ }^{3}$

Efek samping yang dapat terjadi antara lain infeksi saluran napas atas, nasofaringitis, diare, dan folikulitis. ${ }^{27}$ Brodalumab tidak boleh digunakan 
sebagai pilihan pengobatan pada pasien dengan keinginan bunuh diri, perilaku percobaan bunuh diri, atau riwayat keinginan bunuh diri. Kontraindikasi lainnya berupa hipersensitivitas terhadap bahan obat, pasien dengan IBD, dan infeksi aktif. Brodalumab mempunyai level of evidence I-II dengan rekomendasi A dan kategori kehamilan B. $^{21}$

\section{Guselkumab}

Guselkumab merupakan antibodi monoklonal IgG1 $\lambda$ humanized yang menghambat IL-23p19. FDA telah menyetujui guselkumab untuk pengobatan psoriasis plak sedang hingga berat setelah selesainya 2 uji klinis fase III pada tahun 2017. ${ }^{21}$ Dosis pemberiannya diawali dengan dosis $100 \mathrm{mg}$ secara subkutan pada minggu ke-0 dan 4, kemudian dilanjutkan dengan dosis $100 \mathrm{mg}$ setiap 8 minggu. Terdapat suatu studi yang membandingkan guselkumab dengan adalimumab dan plasebo untuk pengobatan psoriasis sedang hingga berat. Pada minggu ke 16, didapatkan $70 \%$ pasien yang mendapatkan guselkumab mencapai PASI 90, dibandingkan dengan $46,8 \%$ pada kelompok adalimumab, dan 2,4\% pada kelompok plasebo. $^{28}$

Efek samping yang dapat terjadi antara lain infeksi saluran napas atas, nasofaringitis, folikulitis, gangguan muskuloskeletal, pruritus, eritema, dan reaksi injeksi. ${ }^{29,30}$ Kontraindikasi pemberian guselkumab berupa hipersensitivitas terhadap bahan obat dan infeksi aktif. Guselkumab mempunyai level of evidence I dengan rekomendasi A dan kategori kehamilan masih belum ada sampai saat ini. ${ }^{21}$

\section{Tildrakizumab}

Tildrakizumab adalah antibodi monoklonal

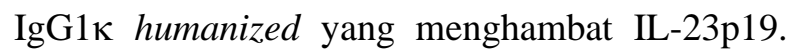
FDA telah menyetujui tildrakizumab sebagai terapi psoriasis derajat sedang-berat pada tahun 2018. ${ }^{21}$ Dosis yang direkomendasikan $100 \mathrm{mg}$ secara subkutan pada minggu ke-0 dan 4, dan kemudian diulang setiap 12 minggu.

Dari suatu penelitian (reSURFACE 2) pada 1090 pasien psoriasis plak derajat sedang hingga berat menunjukkan tildrakizumab dosis $100 \mathrm{mg}$ dan 200 mg efektif mencapai PASI-75 pada $61 \%$ dan 66\%, jika dibandingkan dengan plasebo sebanyak $6 \%$ dan etanercept sebanyak $48 \%$. Terdapat penelitian serupa lainnya (reSURFACE
1) pada 772 pasien psoriasis plak derajat sedang hingga berat. Pada minggu ke 12, 62\% pada kelompok $200 \mathrm{mg}$ dan $64 \%$ pada kelompok $100 \mathrm{mg}$ mencapai PASI-75, dibandingkan dengan 6\% pada kelompok plasebo. Efek samping yang dapat terjadi adalah infeksi saluran napas atas, nasofaringitis, eritema, dan reaksi injeksi. ${ }^{31}$

Kontraindikasi pemberian tildrakizumab antara lain hipersensitivitas terhadap bahan obat dan infeksi aktif. Tildrakizumab mempunyai level of evidence I dengan rekomendasi A dan kategori kehamilan masih belum ada sampai saat ini. ${ }^{21}$

\section{Risankizumab}

Risankizumab adalah antibodi monoklonal IgG1 humanized yang menghambat IL-23p19. Risankizumab telah disetujui oleh FDA sebagai terapi untuk psoriasis derajat sedang-berat pada tahun 2019.32,33 Dosis yang direkomendasikan adalah $150 \mathrm{mg}$ secara subkutan pada minggu ke-0 dan 4, dan kemudian diulang setiap 12 minggu.

Terdapat uji fase III, acak tersamar ganda pada 605 yang mendapat risankizumab $150 \mathrm{mg}$ atau adalimumab $80 \mathrm{mg}$ pada saat awal, kemudian 40 mg pada minggu ke- 1,3 , dan 5 dan setiap minggu setelahnya. Pada minggu ke-16, PASI-90 dicapai oleh $72 \%$ pasien dengan risankizumab dan $47 \%$ pasien adalimumab. Terdapat uji fase III lainnya yang menunjukkan bahwa pada akhir minggu ke16 PASI-90 tercapai antara $72-75 \%$ pada kelompok risankizumab dosis $150 \mathrm{mg}$, dibandingkan dengan 2\%-4,9\% kelompok plasebo, dan $42-48 \%$ pada kelompok ustekinumab. ${ }^{32}$ Terdapat meta analisis yang membandingkan efektivitas jangka pendek dan jangka panjang antara obat biologik dan obat oral lainnya untuk pengobatan psoriasis sedang hingga berat. Pada minggu 10-16, PASI-90 tertinggi dicapai oleh kelompok risankizumab $(71,6 \%)$, kemudian diikuti oleh brodalumab $(70,8 \%)$, ixekizumab $(70,6 \%)$, dan guselkumab $(67,3 \%)$. Setelah 44-60 minggu, PASI-90 dicapai oleh 79,4\% dari kelompok risankizumab, kemudian diikuti oleh guselkumab $(76,5 \%)$, brodalumab $(74,0 \%)$, dan ixekizumab $(73,9 \%) \cdot{ }^{34}$

Efek samping yang dapat terjadi adalah infeksi saluran napas atas, artralgia, dan nyeri kepala. Kontraindikasi pemberian risankizumab adalah hipersensitivitas terhadap bahan obat dan infeksi aktif. $^{32,33}$ Risankizumab mempunyai level of evidence I dengan rekomendasi B dan kategori kehamilan masih belum ada sampai saat ini. ${ }^{21}$ 


\section{Pemeriksaan Penunjang sebelum Memulai Obat Biologik}

Sebelum memulai terapi dengan obat biologik perlu dilakukan skrining untuk memastikan tidak ada kontraindikasi pemberian obat tersebut. Pada dasarnya pemeriksaan untuk semua jenis obat biologik sama, terutama skrining infeksi tuberkulosis aktif pada pasien. Pemeriksaan infeksi tuberkulosis disesuaikan dengan ketersediaan alat pada fasilitas kesehatan, antara lain rontgen toraks atau interferon gamma release assays (IGRA). Selain itu juga perlu dilakukan pemeriksaan seperti darah perifer lengkap, enzim hati, fungsi ginjal, profil lipid, gula darah sewaktu, elektrolit, $c$ reactive protein (CRP), penanda hepatitis, dan HIV. Untuk anti IL-17 (secukinumab, ixekizumab, brodalumab) perlu dilakukan pemeriksaan skrining IBD. ${ }^{11,21}$

\section{Biosimilar}

Biosimilar adalah protein kompleks berukuran besar yang sangat mirip dengan produk referensi biologisnya (obat biologik). ${ }^{35}$ Untuk dapat disetujui sebagai biosimilar, biologis tertentu, harus memenuhi beberapa syarat, yaitu harus sangat mirip dengan produk referensi dan tidak boleh memiliki perbedaan yang bermakna secara klinis dalam hal keamanan atau kemanjuran, disetujui untuk indikasi dan kondisi yang sama, memiliki bentuk dan dosis yang sama, serta memiliki mekanisme kerja yang sama dengan produk referensi. ${ }^{36}$

Biosimilar bukanlah salinan persis, namun menyerupai produk referensi biologisnya. Perbedaan biosimilar dengan produk referensinya antara lain terjadi pada saat pembuatan, misalnya karena proses pemurnian, glikosilasi, dan modifikasi pasca-translasi. Akibatnya, diperlukan bukti tambahan untuk menunjukkan bahwa pertukaran produk referensi dengan biosimilar bersifat aman dan efektif. Salah satu keunggulan biosimilar yaitu harga yang lebih murah 25-30\% dibandingkan dengan produk referensi, sehingga lebih terjangkau oleh masyarakat luas. ${ }^{37}$

Sejak tahun 2016, sudah terdapat beberapa biosimilar untuk terapi psoriasis yang disetujui oleh FDA, yaitu: ${ }^{36,38}$

- Amjevita (adalimumab-atto), Abrilada (adalimumab-afzb), Cyltezo (adalimumab-adbm), Hadlima (adalimumab-bwwd), Hulio (adalimumab- fkjp) dan Hyrimoz (adalimumab-adaz) adalah biosimilar untuk adalimumab (Humira ${ }^{\circledR}$ )

- Erelzi (etanercept-szzs) dan Eticovo (etanercept-ykro) adalah biosimilar untuk etanercept (Enbrel $\left.{ }^{\circledR}\right)$

- Avsola (infliximab-axxq), Inflectra (infliximab-dyyb), Ixifi (infliximab-qbtx) dan Renflexis (infliximab-abda) adalah biosimilar untuk infliximab (Remicade $\left.{ }^{\circledR}\right)$.

Terdapat satu studi yang menilai efektivitas dan keamanan antara biosimilar etanercept (GP2015) dan etanercept (Enbrelß) pada pasien dengan psoriasis tipe plak kronis sedang hingga 109 Sebanyak 531 pasien dirandomisasi untuk Inenuapat GP2015 atau Enbrel ${ }^{\circledR}$ dengan dosis 50 mg dua kali seminggu secara subkutan. Setelah 12 minggu didapatkan PASI-75 pada kelompok GP2015 sebesar 73,4\% sedangkan pada kelompok sebesar $75,7 \%$. Efek samping yang muncul akibat pengobatan sebanding antara kelompok biosimilar dan Enbrel. ${ }^{39}$ Terdapat sebuah telaah sistematik yang membandingkan etanercept dengan GP2015, setelah 12 minggu PASI-75 pada kelompok etanercept adalah $72 \%$ sedangkan pada kelompok GP2015 adalah 70\%. Sehingga tidak terdapat perbedaan efektivitias bermakna antara biosimilar dan produk referensinya. ${ }^{40}$

Papp dkk. melakukan uji acak tersamar ganda untuk menilai kesamaan efektivitas biosimilar adalimumab (ABP 501) dibandingkan dengan adalimumab pada 350 pasien dengan psoriasis sedang hingga berat. Pasien dirandomisasi untuk mendapatkan ABP 501 atau adalimumab dengan dosis inisial adalah $80 \mathrm{mg}$ subkutan dan dilanjutkan 1 minggu kemudian dengan dosis 40 mg yang diberikan setiap 2 minggu. Pada minggu ke-16, pasien dengan PASI-50 atau lebih pada kelompok ABP 501 akan melanjutkan pengobatan yang sama, sedangkan pasien pada kelompok adalimumab akan dirandomisasi ulang ke kelompok adalimumab atau ABP 501 sampai minggu ke-52. PASI-75 pada minggu 16 adalah 80,9\% untuk ABP 501 dan 83,1\% untuk adalimumab. Sayangnya hasil penelitian minggu ke-52 tidak ditampilkan pada penelitian ini. ${ }^{41}$

\section{Penutup}

Pilihan terapi sistemik untuk psoriasis derajat sedang hingga berat yang tersedia saat ini sangatlah beragam. Terapi dengan obat biologik anti-IL17, anti-IL12/23, anti-IL23, dan anti-TNF $\alpha$ 
menunjukkan keunggulan yang signifikan dibandingkan dengan terapi small molecules dan obat sistemik konvensional dalam pencapaian PASI-75, PASI-90, dan PASI-100. Obat anti-IL17 (ixekizumab, brodalumab) dan obat anti-IL23 (risankizumab, guselkumab) secara signifikan lebih efektif dibandingkan dengan anti-IL12/23 dan semua anti-TNF $\alpha$ (kecuali infliximab). Walaupun demikian, untuk mengoptimalkan manajemen penyakit, pemilihan terapi harus tetap mempertimbangkan komorbiditas, riwayat pengobatan sebelumnya, tolerabilitas, keamanan, dan pilihan pasien.

\section{Daftar Pustaka}

1. Armstrong AW, Read C. Pathophysiology, clinical presentation, and treatment of psoriasis: A review. JAMA. 2020;323:194560.

2. Conrad C, Gilliet M. Psoriasis: from pathogenesis to targeted therapies. Clin Rev Allergy Immunol. 2018;54:102-13.

3. Cheungpasitporn W, Sawyer LM, Malottki K, Sabry-Grant C, Yasmeen N, Wright E, et al. Assessing the relative efficacy of interleukin17 and interleukin-23 targeted treatments for moderate-to-severe plaque psoriasis: a systematic review and network meta-analysis of PASI response. Plos One. 2019;14:1-31.

4. Abrouk M, Nakamura M, Zhu TH, Farahnik B, Koo J, Bhutani T. The impact of PASI 75 and PASI 90 on quality of life in moderate to severe psoriasis patients. J Dermatolog Treat. 2017;28:488-91.

5. Rendon A, Schakel K. Psoriasis pathogenesis and treatment. Int J Mol Sci. 2019;20:1-28.

6. Gudjonsson JE, Elder JT. Psoriasis. In: Kang S AM, Bruckner AL, Enk AH, Margolis DJ, McMichael AJ, dkk, editor. Fitzpatrick's dermatology. 9 ed. New York: McGraw Hill Education; 2019. p. 457-97.

7. Sasson SC, Gordon CL, Christo SN, Klenerman P, Mackay LK. Local heroes or villains: tissue-resident memory $\mathrm{T}$ cells in human health and disease. Cell Mol Immunol. 2020;17:113-22.

8. Girolomoni G, Strohal R, Puig L, Bachelez H, Barker J, Boehncke WH, et al. The role of IL23 and the IL-23/TH 17 immune axis in the pathogenesis and treatment of psoriasis. J Eur Acad Dermatol Venereol. 2017;31:1616-26.
9. Xu QN, Zhu HQ. The roles of skin resident memory $\mathrm{T}$ cells in dermatoses. Int J Dermatol Venerol. 2019;2:29-32.

10. Khalil S, Bardawil T, Kurban M, Abbas O. Tissue-resident memory $\mathrm{T}$ cells in the skin. Inflamm Res. 2020;69:245-54.

11. Novianto E, Fitri EM, Budianti WK, penyunting. Alur tata laksana psoriasis vulgaris (tipe plak) di Indonesia. 1 ed. Jakarta: Perhimpunan Dokter Spesialis Kulit dan Kelamin Indonesia; 2019. 1-22 p.

12. Menter A, Gelfand JM, Connor C, Armstrong AW, Cordoro KM, Davis DMR, et al. Joint American academy of dermatology-national psoriasis foundation guidelines of care for the management of psoriasis with systemic nonbiologic therapies. J Am Acad Dermatol. 2020;82:1445-86.

13. Sbidian E, Chaimani A, Afach S, Doney L, Dressler C, Hua C, et al. Systemic pharmacological treatments for chronic plaque psoriasis: a network meta-analysis. Cochrane Database Syst Rev. 2020;1:1-604.

14. Ronholt K, Iversen L. Old and new biological therapies for psoriasis. Int $\mathrm{J}$ Mol Sci. 2017;18:1-23.

15. Papp K, Reich K, Leonardi CL, Kircik L, Chimenti S, Langley RG, et al. Apremilast, an oral phosphodiesterase 4 (PDE4) inhibitor, in patients with moderate to severe plaque psoriasis: results of a phase III, randomized, controlled trial (Efficacy and Safety Trial Evaluating the Effects of Apremilast in Psoriasis [ESTEEM] 1). J Am Acad Dermatol. 2015;73:37-49.

16. Tegtmeyer K, Zhao J, Maloney NJ, Atassi G, Beestrum M, Lio PA. Off-label studies on tofacitinib in dermatology: a review. $\mathrm{J}$ Dermatolog Treat. 2019;1:1-11.

17. Papp KA, Menter MA, Abe M, Elewski B, Feldman SR, Gottlieb AB, et al. Tofacitinib, an oral Janus kinase inhibitor, for the treatment of chronic plaque psoriasis: results from two randomized, placebo-controlled, phase III trials. Br J Dermatol. 2015;173:949-61.

18. Berekmeri A, Mahmood F, Wittmann M, Helliwell P. Tofacitinib for the treatment of psoriasis and psoriatic arthritis. Expert Rev Clin Immunol. 2018;14:719-30.

19. Arnone M, Takahashi MDF, Carvalho AVEd, Bernardo WM, Bressan AL, Ramos AMC, et al. Diagnostic and therapeutic guidelines for plaque psoriasis - Brazilian society of 
dermatology. Anais Brasileiros de Dermatologia. 2019;94:76-107.

20. Smith CH, Yiu ZZN, Bale T, Burden AD, Coates LC, Edwards W, et al. British association of dermatologists guidelines for biologic therapy for psoriasis 2020: a rapid date. Br J Dermatol. 2020;183:628-37.

131 enter A, Strober BE, Kaplan DH, isvelevitch D, Prater EF, Stoff B, et al. Joint AAD-NPF guidelines of care for the management and treatment of psoriasis with biologics. J Am Acad Dermatol. 2019;80:1029-72.

22. Bissonnette R, Luger $\mathrm{T}$, Thaci $\mathrm{D}$, Toth $\mathrm{D}$, Lacombe A, Xia S, et al. Secukinumab demonstrates high sustained efficacy and a favourable safety profile in patients with moderate-to-severe psoriasis through 5 years of treatment (SCULPTURE Extension Study). J Eur Acad Dermatol Venereol. 2018;32:150714.

23. Neema S, Singh S, Pathak N, Khan MA. Widespread superficial dermatophytosis in patient on secukinumab for treatment of chronic plaque psoriasis. Indian Dermatol Online J. 2019;10:76-8.

24. Bai F, Li GG, Liu Q, Niu X, Li R, Ma H. Shortterm efficacy and safety of IL-17, IL-12/23, and IL-23 inhibitors brodalumab, secukinumab, ixekizumab, ustekinumab, guselkumab, tildrakizumab, and risankizumab for the treatment of moderate to severe plaque psoriasis: a systematic review and network meta-analysis of randomized controlled trials. J Immunol Res. 2019;2019:1-25.

25. Cui L, Chen R, Subedi S, Yu Q, Gong Y, Chen $\mathrm{Z}$, et al. Efficacy and safety of biologics targeting IL-17 and IL-23 in the treatment of moderate-to-severe plaque psoriasis: a systematic review and meta-analysis of randomized controlled trials. Int Immunopharmacol. 2018;62:46-58.

26. Lebwohl M, Strober B, Menter A, Gordon K, Weglowska J, Puig L, et al. Phase 3 studies comparing brodalumab with ustekinumab in psoriasis. N Engl J Med. 2015;373:1318-28.

27. Nakagawa H, Niiro H, Ootaki K. Brodalumab, a human anti-interleukin-17-receptor antibody in the treatment of Japanese patients with moderate-to-severe plaque psoriasis: efficacy and safety results from a phase II randomized controlled study. J Dermatol Sci. 2016;81:4452.
28. Reich K, Armstrong AW, Foley P, Song M, Wasfi Y, Randazzo B, et al. Efficacy and safety of guselkumab, an anti-interleukin-23 monoclonal antibody, compared with adalimumab for the treatment of patients with moderate to severe psoriasis with randomized withdrawal and retreatment: results from the phase III, double-blind, placebo and active comparator-controlled VOYAGE 2 trial. J Am Acad Dermatol. 2017;76:418-31.

29. Nemoto O, Hirose K, Shibata S, Li K, Kubo H. Safety and efficacy of guselkumab in Japanese patients with moderate-to-severe plaque psoriasis: a randomized, placebo-controlled, ascending-dose study. B J Dermatol. 2018;178:689-96.

30. Langley RG, Tsai TF, Flavin S, Song M, Randazzo B, Wasfi Y, et al. Efficacy and safety of guselkumab in patients with ps who have an inadequate respon 110 ustekinumab: results of the randomized, double-blind, phase III NAVIGATE trial. Br J Dermatol. 2018;178:114-23.

31. Reich K, Papp KA, Blauvelt A, Tyring SK, Sinclair R, Thaçi D, et al. Tildrakizumab versus placebo or etanercept for chronic plaque psoriasis (reSURFACE 1 and reSURFACE 2): results from two randomised controlled, phase 3 trials. The Lancet. 2017;390:276-88.

32. Li W, Ghamrawi R, Haidari W, Feldman SR. Risankizumab for the treatment of moderate to severe plaque psoriasis. Ann Pharmacother. 2020;54:380-87.

33. McKeage K, Duggan S. Risankizumab: first global approval. Drugs. 2019;79:893-900.

34. Armstrong AW, Puig L, Joshi A, Skup M, Williams $\mathrm{D}, \mathrm{Li} \mathrm{J}$, et al. Comparison of biologics and oral treatments for plaque psoriasis: a meta-analysis. JAMA Dermatol. 2020;156:258-69.

35. Kellen R, Goldenberg G. Biosimilars in psoriasis: the future or not? Cutis. 2017;99:116-20.

36. Feagan BG, Lam G, Ma C, Lichtenstein GR. Systematic review: efficacy and safety of switching patients between reference and biosimilar infliximab. Aliment Pharmacol Ther. 2019;49:31-40.

37. Cohen AD, Wu JJ, Puig L, Chimenti S, Vender $\mathrm{R}$, Rajagopalan $\mathrm{M}$, et al. Biosimilars for psoriasis: worldwide overview of regulatory guidelines, uptake and implications for dermatology clinical practice. Br J Dermatol. 2017; 177:1495-502. 
38. National Psoriasis Foundation. Biologic \& biosimilars for psoriasis. [Internet]. 2020. [cited 2020 Oct 30]. Available from: https://www.psoriasis.org/biologics/.

39. Puig L, Lopez-Ferrer A. Biosimilars for the treatment of psoriasis. Expert Opin Biol Ther. 2019;19:993-1000.

40. Moots RJ, Curiale C, Petersel D, Rolland C, Jones H, Mysler E. Efficacy and safety outcomes for originator TNF inhibitors and biosimilars in rheumatoid arthritis and psoriasis trials: a systematic literature review. BioDrugs. 2018;32:193-9.

41. Papp K, Bachelez H, Costanzo A, Foley P, Gooderham M, Kaur $P$, et al. Clinical similarity of biosimilar ABP 501 to adalimumab in the treatment of patients with moderate to severe plaque psoriasis: a randomized, double-blind, multicenter, phase III study. J Am Acad Dermatol. 2017;76:1093102. 